\title{
GAMBARAN WORK-LIFE BALANCE PADA JAKSA WANITA YANG TELAH BERKELUARGA
}

\author{
Iwinda Pratama Hae ${ }^{1}$ \& Ratriana Y.E.Kusumiati ${ }^{2}$ \\ Email : iwindahae24@gmail.com ${ }^{1}$ \\ Fakultas Psikologi Universitas Kristen Satya Wacana ${ }^{1,2}$
}

\begin{abstract}
Married women who are working will encounter double roles. Participants in this study involve married female prosecutors having a family and children. Based on the initial interview with the participants, the prosecutors has a long responsibility starts from the investigation process with the police department, witness interrogation, case analysis and making the lawsuit, until the process of transferring the lawsuit to the court and convincing the judge with the lawsuit. Finally, the prosecutors also take an action in executing the criminals. They sometimes confront with the system problem versus their conscience which causes job stress and it influences on their family or they are on the conflict situation. However, there is also an enhancement situation; the job gives a positive advantage to the participants. The purpose of this study is to get the description of work-life balance on married female prosecutors having a family. The method used in this study is qualitative with the phenomenology approach of collecting data is by interview. There are 5 main themes in this study, such as job, family, experience of work-life balance, strategy and balance achievement. The result of this study shows that having double roles or experience of work-life balance, both participants experience similar conflict dynamics and enhancement orexperience ofwork-life balance. Both participants also make a perception that theyhave been in balance so far. They keep trying to be professional in working and also to spare their time be with their family.
\end{abstract}

Keywords: Work-Life Balance, Conflict, Enhancement, Female Prosecutors, Married

\begin{abstract}
Abstrak
Wanita yang bekerja dan berkeluarga akan diperhadapkan dengan peran ganda. Partisipan penelitian melibatkan jaksa wanita yang telah berkeluarga dan mempunyai anak. Berdasarkan wawancara awal dengan partisipan, jaksa mempunyai tanggung jawab yang panjang mulai dari proses penyidikan bersama polisi, pemeriksaan saksi, analisa perkara dan membuat tuntutan hingga pada tahap melimpahkan perkara ke pengadilan untuk disidangkan dan membuat yakin hakim atas penuntutannya hingga eksekusi. Jaksa terkadang diperhadapkan dengan persoalan sistem vs hati nurani yang berakibat pada job stress dan berpengaruh pada keluarga atau berada dalam situasi conflict. Namun ada pula situasi enhancement yaitu pekerjaan memberi manfaat positif bagi partisipan. Penelitian ini bertujuan untuk mendapat gambaran worklife balance pada jaksa wanita yang telah berkeluarga. Peneliti menggunakan metode penelitian kualitatif dengan pendekatan fenomenologi, metode pengumpulan data menggunakan metode wawancara. Penelitian ini mendapatkan 5 tema utama yaitu pekerjaan, keluarga, pengalaman work-life balance, strategi, dan pencapaian keseimbangan. Hasil penelitian ini menunjukkan bahwa menjalani peran ganda atau dalam pengalaman work-life balance, kedua partisipan mengalami dinamika conflict dan enhancement atau pengalaman work-life balance yang tidak jauh berbeda. Kedua partisipan juga mempersepsi bahwa mereka sudah seimbang. Partisipan berusaha tetap profesional dalam pekerjaan dan tetap memiliki waktu bagi keluarga.
\end{abstract}

Kata kunci : Work-Life Balance, Conflict, Enhancement, Jaksa Wanita, Berkeluarga.

PENDAHULUAN

Persentase tenaga kerja formal

wanita sepanjang tahun 2015 hingga 2017

terus mengalami kenaikan yaitu pada

tahun 2015 persentasenya sebesar 37,78

$\%$, tahun 2016 sebesar 38,16\%, dan tahun

2017 sebesar 38,63 \% (Badan Pusat

Statistik, 2018). Khususnya di NTT, pertumbuhan angkatan kerja perempuan lebih tinggi yaitu 2,28\% dibanding lakilaki yaitu $2,14 \%$. Hal tersebut ditandai dengan adanya peningkatan jumlah angkatan kerja perempuan tahun 20142017. Ini menunjukkan bahwa adanya pergeseran makna tugas perempuan hanyalah mengurus rumah tangga (BPS, 
2017). Usia dewasa dini (18-40 tahun) merupakan periode penyesuaian diri terhadap pola-pola kehidupan baru (peran sebagai suami atau isteri, orang tua, sebagai pencari nafkah, dsb) dan harapanharapan sosial baru. Tugas perkembangan pada periode ini dipusatkan pada harapanharapan masyarakat seperti dalam hal bekerja, belajar hidup bersama dengan suami atau isteri, membentuk keluarga, membesarkan anak-anak, menerima tanggung jawab sebagai warga negara, dan bergabung dalam suatu kelompok sosial yang cocok (Hurlock, 1999). Pada periode ini juga merupakan fase pengembangan karir yaitu memasuki tahap pemantapan yang meliputi usia 25 44 tahun. Pada tahap ini ditandai dengan masuknya individu ke dalam dunia pekerjaan yang sesuai dengannya sehingga ia akan bekerja keras untuk mempertahankan pekerjaannya. Pada usia 31-44 tahun, Ada dua tugas perkembangan yang harus dipenuhi oleh individu pada masa ini yaitu, pertama, individu mengkonsolidasi pilihan pekerjaannya. Pada fase ini, keamanan dan kenyamanan dalam bekerja menjadi tujuan utama, tugas kedua adalah melakukan peningkatan dalam dunia pekerjaannya (Super dalam Putri, 2012).

Berdasarkan hal di atas, jika dikaitkan dengan kehidupan dari wanita yang telah bekerja dan berkeluarga pada usia dewasa dini maka mereka harus berhadapan pada peran dalam pekerjaan mereka dan peran di luar pekerjaan atau di dalam keluarga. Keluarga dan pekerjaan merupakan 2 domain yang tidak bisa dipisahkan satu dengan yang lainnya. Ambiguitas atau konflik yang dialami dalam suatu peran akan menghasilkan keadaan yang tidak diinginkan, oleh karena tuntutan yang saling bertentangan di antara peran-peran yang dijalankan. Saat individu dapat menjalankan kedua perannya dan saling mendukung satu sama lain bukannya bertentangan maka akan terjadi keseimbangan antara pekerjaan dan keluarga atau work-life balance.

Work-life balance dari Fisher (2001) menyatakan bahwa work-life balance atau keseimbangan antara kehidupan pekerjaan dan kehidupan di luar pekerjaan terjadi jika individu mampu mengalokasikan waktu dan energi yang dimiliki tidak hanya untuk bekerja tetapi juga untuk kehidupan di luar pekerjaannya. Selain itu, adanya pencapaian tujuan yang diharapkan dalam dunia kerja dan juga kehidupan di luar pekerjaan. Menurut Fisher, Bulger, dan Smith (2009), ada 4 dimensi work-life balance yaitu : a) Dimensi WIPL (Work Interference With Personal Life). Dimensi ini mengacu pada 
sejauh mana pekerjaan dapat mengganggu kehidupan pribadi individu. b) Dimensi PLIW (Personal Life Interference With Work). Dimensi ini mengacu pada sejauh mana kehidupan pribadi individu mengganggu kehidupan pekerjaannya. c) Dimensi WEPL (Work Enhancement Of Personal Life). Dimensi ini mengacu pada sejauh mana pekerjaan dapat meningkatkan kualitas kehidupan pribadi individu, d) Dimensi PLEW (Personal Life Enhancement Of Work). Dimensi ini mengacu pada sejauh mana kehidupan pribadi seseorang dapat meningkatkan performa individu dalam dunia kerja.

Adapun faktor-faktor yang mempengaruhi seseorang dalam mencapai work-life balance menurut Poulose \& Sudarsan (2014) yaitu gender, psychological well-being, kecerdasan emosi, work arrangements, work support, job stress, childcare responsibilities, family support dan dukungan sosial.

Peran ibu membuat tuntutan yang seringkali tidak dapat dijadwalkan dan yang mungkin diperburuk oleh harapan normatif budaya yaitu "good mothering" atau pengasuhan anak. Tanggung jawab wanita terhadap rumah cenderung lebih besar dan mereka mungkin lebih banyak berkorban jika dibandingkan dengan lakilaki (Milkie \& Peltola, 1999). Anak-anak kecil (young children) dalam rumah tangga memiliki dampak negatif yang signifikan terhadap keberhasilan menyeimbangkan pekerjaan dan kehidupan keluarga (Milkie \& Peltola, 1999). Menurut Eliot (dalam Poulose \& Sudarsan, 2014), kesulitan besar yang dihadapi oleh orang tua yang bekerja khususnya bagi yang memiliki anak usia di bawah 6 tahun adalah memberikan perawatan anak yang memadai. Pengasuhan terhadap anak menjadi tanggung jawab serta tugas perkembangan yang sangat penting karena anak pada umumnya sedang dalam usia-usia yang membutuhkan perhatian besar. Khususnya usia bayi hingga anak akhir. Usia 2-12 tahun yaitu usia kanak-kanak awal (2-6 tahun) dan kanak-kanak akhir (6-12 tahun) umumnya dianggap sebagai usia bermasalah / usia sulit karena masa ini sering terjadi masalah perilaku (bandel, melawan, marah tanpa alasan) sebagai akibat karena anak sedang dalam proses perkembangan kepribadian. Sering juga disebut usia bermain, usia prasekolah, usia menjelajah, usia bertanya, usia meniru, dan usia kreatif (Hurlock dalam Soetjiningsih, 2012).

Orang tua berperan penting sebagai manajer bagi kesempatan-kesempatan yang dimiliki anak-anak, seperti mengawasi perilaku mereka. Praktik manajemen keluarga seperti menciptakan 
rutinitas mengerjakan pekerjaan rumah, waktu tidur, membatasi waktu untuk kegiatan nonproduktif (seperti bermain games). Ibu cenderung lebih berperan sebagai manajer dalam pengasuhan daripada ayah (Santrock, 2012).

Selain berperan di keluarga, wanita juga mempunyai peran di pekerjaannya. Dari segi partisipan, peneliti melibatkan partisipan yang bekerja sebagai jaksa wanita. Jaksa adalah pejabat fungsional yang diberi wewenang oleh undangundang untuk bertindak sebagai penuntut umum dan pelaksana putusan pengadilan yang telah memperoleh kekuatan hukum tetap serta wewenang lain berdasarkan undang-undang (UU No. 16 tahun 2004). Tugas pokok jaksa di bidang pidana adalah melakukan penuntutan; melaksanakan penetapan hakim dan putusan pengadilan yang telah memperoleh kekuatan hukum tetap; melakukan pengawasan terhadap pelaksanaan putusan pidana bersyarat, putusan pidana pengawasan, dan keputusan lepas bersyarat; melakukan penyidikan terhadap tindak pidana tertentu berdasarkan undang-undang; melengkapi berkas perkara tertentu dan untuk itu dapat melakukan pemeriksaan tambahan sebelum dilimpahkan ke pengadilan yang dalam pelaksanaannya dikoordinasikan dengan penyidik. Di bidang perdata, bertindak sebagai pengacara negara. Dan juga berperan dalam hal ketertiban umum (pasal 30 Undang-Undang Nomor 16 Tahun 2004).

Menurut wawancara penjajakan dengan seorang jaksa, dikatakan bahwa jaksa sebagai sentral (posisi strategis) dalam penanganan perkara. Dapat dikatakan semua perkara bermuara pada jaksa penuntut umum. Mulai dari proses penyidikan bersama polri, jaksa harus mengkoordinasikan hingga P21 (salah satu kode dalam administrasi perkara tindak pidana yaitu pemberitahuan bahwa hasil penyidikan sudah lengkap), dan juga pengumpulan saksi, dan pemeriksaan saksi yang bergantung pada jenis perkara yang ditangani. Setelah sudah lengkap, jaksa harus menganalisa perkara dan membuat tuntutan hingga pada tahap melimpahkan perkara ke pengadilan untuk disidangkan. Seorang jaksa yang melakukan penuntutan harus yakin atas tuntutan yang diberikannya dan harus membuat yakin hakim atas penuntutannya. Setelah proses di pengadilan, jaksa juga bertindak mengeksekusi pelaku.

Jaksa juga terkadang diperhadapkan dengan persoalan sistem $v s$ hati nurani. Menurut wawancara awal dengan seorang jaksa lain, dikatakan bahwa jika ada perkara yang berkaitan dengan keluarga 
pimpinan, dia diminta oleh pimpinannya untuk membantu sedikit meringankan tuntutan dari yang seharusnya atau sedikit memanipulasi. Pada akhirnya hati nurani harus tergilas karena sistem dan hal itu menjadi job stress kemudian berpengaruh pada pribadi subjek yang mudah marah dan tidak bahagia di rumah. Hal ini mengindikasikan adanya situasi conflict. Selain pengalaman konflik, partisipan pun juga mendapatkan enhancement yaitu secara psikologis, pekerjaan partisipan membuat partisipan merasa percaya diri karena mendapatkan keterampilan dan juga mendapat kedudukan yang terhormat atau dihargai di tengah lingkungan sosial partisipan. Seorang partisipan lain juga memaparkan dinamikanya dalam mengarungi peran ganda yaitu pekerjaan memberi kontribusi atau enhancement bagi kepribadiannya dimana partisipan menjadi pribadi yang berpikir dahulu sebelum bertindak, \& memandang setiap manusia itu kedudukannya sama atau tidak membeda-bedakan berdasarkan status. Namun partisipan juga mengalami situasi conflict yaitu bekerja di luar jam kerja formal (07.30-16.00) karena harus lembur untuk perkara ataupun untuk sidang. Akibatnya waktu dengan anakanaknya tersita.

Dalam situasi peran ganda atau dalam work-life balance, tuntutan yang tidak terpenuhi atau saling bertentangan dapat menimbulkan konflik. Conflict adalah peran ganda dengan tuntutan tak terbatas biasanya menyebabkan ketegangan dan konflik peran bagi individu karena sumber daya yang mereka miliki hanya dapat menghadapi tuntutan yang terbatas dan langka (Goode, 1960). Selain adanya conflict, pekerjaan juga memiliki dampak positif atau keuntungan bagi individu atau disebut sebagai enhancement. Enhancement adalah peran ganda memberikan keuntungan dalam bentuk hak istimewa, status keamanan, energi psikologis dan pertumbuhan diri yang mana menambah sumber daya individual dan memfasilitasi kinerja (Marks, 1977; Sieber, 1974).

Berdasarkan hasil penelitian sebelumnya oleh Saniy (2018), menyatakan bahwa pekerja wanita dengan jabatan fungsional yang sudah menikah di DP2KBP3A (Dinas Pengendalian Penduduk, Keluarga Berencana, Pemberdayaan Perempuan, dan Perlindungan Anak) Kabupaten Bandung memiliki penghayatan yang berbeda-beda terhadap peran yang dijalani. Pengalaman enhancement dan conflict yang dialami oleh pekerja wanita di DP2KBP3A berbeda-beda. Ada hal-hal yang dirasakan positif dan negatif bagi pekerja wanita dalam menjalani peran ganda. Selain hal 
positif dan negatif yang dirasakan oleh pekerja wanita tersebut, tiga dari tujuh pekerja wanita mengatakan tidak merasa kesulitan untuk menjalankan peran di keluarga dan pekerjaan. Ada pun empat pekerja wanita lainnya merasa kesulitan saat menjalani peran gandanya (Saniy, 2018). Karena perbedaan pengalaman work-life balance yang di dalamnya ada pula dinamika perbedaan situasi conflict dan enhancement, maka peneliti bermaksud mengeksplorasi gambaran work-life balance khususnya pada jaksa wanita.

\section{METODE PENELITIAN}

Penelitian ini menggunakan pendekatan kualitatif. Informan dalam penelitian ini dipilih melalui teknik purposive sampling dengan kriteria jaksa wanita, usia 30-40 tahun, telah menikah, dan mempunyai anak usia bayi hingga anak-anak akhir.

Teknik pengumpulan data yang dilakukan dalam penelitian ini adalah wawancara semi-terstruktur dengan menggunakan pedoman wawancara yang tidak diikuti secara ketat. Pertanyaan wawancara yang diberikan tidak selalu merupakan urutan kaku tetapi atas dasar dinamika yang berkembang selama wawancara. Proses wawancara dilakukan dalam 2 kali pertemuan, berkisar 30 menit hingga 60 menit untuk setiap pertemuan.
Alat pengumpulan data yang digunakan dalam penelitian ini adalah alat perekam dan buku catatan. Penelitian ini dilakukan di kota kupang, Nusa Tenggara Timur.

Data yang diperoleh dianalisis menggunakan interpretative phenomenological analysis (IPA). Langkah-langkah analisis data yang dilakukan mengacu pada usulan Smith \& Osborn (2009), yaitu: pertama, mentranskrip seluruh data hasil wawancara berupa verbatim. Kemudian peneliti melakukan pengkodean dengan cara memberikan komentar pada masingmasing transkrip dan dituliskan di margin sebelah kiri.

Berikutnya, komentar komentar awal di marjin kiri tiap transkrip dibaca ulang untuk mendapatkan label-label yang lebih konseptual. Label-label konseptual di marjin kanan pada semua transkrip kemudian dikelompokkan berdasarkan kesamaan maknanya dan tiap kelompok ini diberi nama subtema. Seluruh subtema dikelompokkan kembali berdasarkan kedekatan cakupan maknanya dan diberi nama tema utama (superordinate themes). Seluruh proses pengkodingan ini bermuara pada hasil akhir berupa tabel tema hasil penelitian. Tabel tema inilah yang menjadi dasar penulisan laporan. Sebagai upaya untuk menjamin transparansi penelitian, peneliti mengutip 
ekstrak-ekstrak dari data asli dalam paparan hasil penelitian agar pembaca dapat menilai interpretasi dari peneliti. Pada ekstrak wawancara peneliti menggunakan tanda “[...]" untuk menunjukkan ada bagian kecil dari data asli yang dihapus untuk tujuan memperlancar maksud partisipan. Sedangkan kata atau kalimat dalam tanda "( )" dalam ekstrak kutipan merupakan klarifikasi makna peneliti atas maksud partisipan.

Penelitian ini menggunakan validasi responden dan trianggulasi perspektif untuk menguji validitas. Validasi responden adalah mengecek ulang data dengan cara menunjukkan hasil salinan verbatim wawancara beserta analisis dari peneliti kepada partisipan. Trianggulasi perspektif yaitu dengan menggunakan perspektif orang lain atau informan yang paham benar dengan partisipan penelitian (Herdiansyah, 2015). Informan yang terlibat dalam penelitian ini adalah teman kantor dari partisipan 1 dan suami dari partisipan 2.

\begin{tabular}{|l|c|c|}
\hline Partisipan & $\begin{array}{c}\text { Partisipan } \\
1(\mathrm{C})\end{array}$ & $\begin{array}{c}\text { Partisipan } \\
2(\mathrm{~S})\end{array}$ \\
\hline Umur & 39 tahun & 35 tahun \\
\hline Profesi & $\begin{array}{c}\text { Jaksa } \\
\text { (perdata) }\end{array}$ & $\begin{array}{c}\text { jaksa } \\
\text { (pidana) }\end{array}$ \\
\hline $\begin{array}{l}\text { Jumlah } \\
\text { anak }\end{array}$ & 2 & 2 \\
\hline $\begin{array}{l}\text { Umur } \\
\text { anak }\end{array}$ & $\begin{array}{c}9 \& 3 \\
\text { tahun }\end{array}$ & $\begin{array}{c}7 \text { \& } 11 \\
\text { tahun }\end{array}$ \\
\hline
\end{tabular}

\section{HASIL DAN PEMBAHASAN}

Penelitian ini menghasilkan 5 tema utama yaitu pekerjaan, keluarga, pengalaman work-life balance, strategi, pencapaian keseimbangan. Dari tema pekerjaan, kedua partisipan bekerja di bidang yang berbeda sehingga dari segi work arrangements memiliki perbedaan. Partisipan 1 berada di bidang perdata dan TUN (tata usaha negara) yang tugasnya menjadi pengacara negara atau memberi pendapat hukum. Menurut partisipan 1, bidang kerjanya tidak terlalu dikejar deadline kecuali dalam hal sidang atau bidang kerjanya bersifat fleksibel sehingga semenjak pindah ke bidang perdata, partisipan 1 sudah mulai seimbang. Jika dibandingkan dengan bidang pidana atau yang menangani perkara, lebih dikejar deadline. Teman kantor dari partisipan membenarkan hal itu. Partisipan 2 berada di bidang pidana dan menurutnya beban kerjanya lumayan berat karena dari segi waktu kerja tidak berbatas pada waktu kerja formal saja. Suami partisipan 2 mengatakan bahwa terkadang waktu bersama keluarga tersita karena istrinya harus lembur untuk perkara tertentu ataupun harus antre untuk sidang. Pengaturan jam kerja yang fleksibel dapat membantu pekerja untuk menyeimbangkan perannya dalam 
pekerjaan dan kehidupan di luar pekerjaan (Poulose \& Sudarsan, 2014).

"Kalo beban kerja, [...] di pidana umum, pidana khusus yaaa itu mungkin agak sukar karena waktunya diatur. Kalau kami tu waktunya fleksibel" (104-120 P1).

"Beban kerjanya, cukup berat sih. Euh...euh, kalo untuk jam kerja, [...] formilnya sih, kita masuk kantor jam 8, pulang jam 4. Tapi kenyataannya [...] lebih dari itu, kadang kita pulang malem" (142-149 P2).

Dorongan partisipan untuk bekerja adalah untuk menjadi lebih baik lagi dan untuk aktualisasi diri. Partisipan 2 terdorong untuk bekerja karena awalnya ia sudah sekolah di SMA kejaksaan, kemudian partisipan 2 menjadi tata usaha di kejaksaan sehingga ia terdorong untuk lebih baik lagi. Ditambah karena adanya dorongan dari ayahnya bahwa ia bukanlah apa-apa di kejaksaan ketika belum menjadi jaksa. Sedangkan partisipan 1 terdorong untuk bekerja karena partisipan 1 sudah menempuh kuliah hukum dan ingin agar kemampuannya dapat digunakan atau untuk aktualisasi diri. Handayani, Afiati \& Adiyanti (2015) dalam penelitiannya menemukan bahwa wanita memaknai bekerja sebagai aktualisasi diri karena merasa mempunyai kemampuan.
"Ohhh... ya karena saya kan sudah kuliah hukum, jadi ya sudah saya cari kerja. Dan memang supaya kemampuan saya bisa digunakan ya untuk aktualisasikan diri gitu..." (1698-1702 P1)

"[...] karena sayasudah bekerja di kejaksaan, artinya, saya kan masuk dari SMA [...] saya ingin lebih maju lagi [...]. Saya harus kuliah, setelah saya kuliah, ada kesempatan, kenapa nggak saya coba..?, untuk tes jadi jaksa" (76-90 P2).

Kedua partisipan memahami peran sebagai ibu dan istri di keluarga dan menganggap keluarga adalah segalanya. Bagi kedua partisipan, keluarga adalah segalanya. Partisipan 2 memahami perannya dalam keluarga yaitu sebagai ibu, yaitu harus bisa jadi apapun / peran ibu tidak terbatas bagi anak. Sebagai istri, partisipan 2 memahami perannya sebagai teman sepadan, menjadi sekretaris dan bendahara. Al Qarasi (dalam Wijayanto dan Fauziah, 2018) mengungkapkan tugas seorang ibu rumah tangga sebagai akuntan keluarga yaitu mengelola pendapatan dan anggaran belanja keluarga dengan sebaikbaiknya.

"Buat saya keluarga segalanya. Pekerjaan mungkin yah... Tuhan titip untuk saya ini lah..ada lah dalam kehidupan saya supaya ada keseimbangan.. tapi keluarga tetap segalanya buat saya" (712-717 P1). 
“[...] arti keluarga...ya segala-galanya buat saya.[...]. Keluarga itu tempat saya pulang.[...] Saat saya sedih, saya pulang. Dengan cara, ya saya peluk suami saya, saya peluk anak-anak saya” (771-797 P2).

Kedua partisipan mendapat dukungan dari keluarga mereka, yaitu partisipan 1 mendapat dukungan dari mertuanya dalam hal pengasuhan anak. Hal ini juga dibenarkan oleh teman kantor partisipan 1 yaitu tentang pengalaman menitipkan anak pada mertua. Partisipan 2 mendapat dukungan dari suaminya sepenuhnya untuk menjadi wanita karir.

Family support atau dukungan sosial dari keluarga sangat berpengaruh pada tingkat work-life balance pada seseorang. Dukungan sosial keluarga yang tinggi cenderung berhubungan dengan tingkat work-life balance yang tinggi pula pada seorang pekerja (Poulose \& Sudarsan, 2014).

“[...].jadi ketika saya punya anak pertama itu saya sudah lebih santai karena masih sama mertua.[...]. jadi anak sepenuhnya sama oma.[...]. Jadi waktu saya menangani perkara pidana memang saya lebih banyak full ke ini, ke kantor" (643$661 \mathrm{P} 1)$.

"Jadi, suami saya tu mendukung sepenuhnya.." (1370-1386 P2).

Dalam situasi peran ganda atau dalam work-life balance, Tuntutan yang tidak terpenuhi atau saling bertentangan dapat menimbulkan konflik (Goode, 1960). Partisipan 1 pernah berada dalam situasi tidak adanya pengasuh bagi anak balitanya sehingga partisipan 1 harus meninggalkan kantor padahal pekerjaan masih banyak. Hal itu menjadi beban untuknya. Dalam hal ini, partisipan 1 sedang dalam situasi yang menurut Greenhaus (dalam Indriyani, 2009), timebased conflict yaitu waktu yang dibutuhkan untuk menjalankan salah satu tuntutan (keluarga atau pekerjaan) dapat mengurangi waktu untuk menjalankan tuntutan yang lainnya (pekerjaan atau keluarga). Partisipan 1 juga mengalami Job stress (penanganan kasus yang mengorbankan hati nurani karena sistem berupa SOP atau adanya intervensi pimpinan) yang membuatnya menjadi tidak happy dan mudah marah di rumah. Dalam hal ini, partisipan 1 berada dalam situasi Strain-based conflict yaitu terjadi tekanan dari salah satu peran mempengaruhi kinerja peran lainnya. Salah satu faktor yang mempengaruhi work-life balance adalah job stress. Job stress merupakan situasi tegang atau tidak nyaman di lingkungan pekerjaan yang cenderung membuat individu merasa tertekan (Poulose \& Sudarsan, 2014).

“[...] ketika tidak ada yang jaga apalagi balita, kan dia masih butuh perhatian 
ekstra, [...] mau tidak mau saya harus meninggalkan kantor. [...]. Ketika anak masih balita dan pekerjaan kantor masih banyak, [...] itu adalah bebannya" (305320 P1).

"Ya ! ada ya efeknya. Dan saya juga kasian sama anak saya waktu itu.[...].Karena waktu itu, saya bawa, setiap saya baca berkas tu, saya berusaha untuk...jangan ada suara.[...]Saya suka yang hening.[...]Karena kalo mereka bersuara, saya marah ![...]saya bilang pergi jauh jauh di kamar sebelah !Akhirnya mereka yang jadi..nggak bisa deket saya" (598-621 P2).

Partisipan 2 juga mengalami timebased conflict yaitu partisipan 2 kehilangan kedekatan dengan anak karena membawa pekerjaan ke rumah. Suami partisipan 2 menyatakan bahwa terkadang urusan kantor membuat waktu dengan keluarga berkurang. Hal ini sesuai dengan penelitian Milkie (2010) bahwa wanita pekerja yang kurang mampu menyeimbangkan kehidupan keluarganya akan cenderung memiliki kualitas interaksi yang buruk dengan anakanaknya. Kedua partisipan juga mengalami enhancement. Partisipan 1 mengakui bahwa pekerjaan membuatnya mendapat kedudukan istimewa di tengah masyarakat dan juga mengasah intuisinya dalam menghadapi kehidupan. Dan pekerjaan membuat partisipan 2 menjadi pribadi yang tidak asal bicara dan tidak membedakan orang berdasarkan latar belakang. Menurut pernyataan suami partisipan 2, partisipan mendapat enhancement yaitu menjadi pribadi yang tidak asal bicara.

"karena pekerjaan , kita dihargai, [...], dalam masyarakat dapat posisi yang baik artinya bahwa ohh itu ibu jaksa.[...] labelling dari masyarakat pasti ada" (252258 P1).

"Kehidupan sehari-hari [...]cara saya berkomunikasi [...]. Saya, nggak asal asal ngomong gitu" (1606-1615 P2).

Kedua partisipan memiliki strategi yang sama dalam mengatasi situasi work interference with personal life yaitu dengan dengan membagi waktu antara rumah dan keluarga. Senin sampai jumat untuk pekerjaan, sabtu dan minggu untuk keluarga. Meskipun begitu, ada hal situasional yang terjadi seperti saat tidak pengasuh bagi anaknya sehingga partisipan 1 mengambil pekerjaan kantor dan dibawa ke rumah. Tapi bagi partisipan 2, sama sekali tidak ingin lagi membawa pekerjaan kantor ke rumah pada hari sabtu dan minggu, karena dalam pengalamannya, partisipan 2 pernah kehilangan kedekatan dengan anaknya karena hal tersebut. Suami partisipan 2 mengatakan bahwa setiap hari sabtu dan 
minggu, istrinya akan mematikan handphone untuk menghabiskan waktu yang berkualitas bersama keluarga. Kreiner (dalam Allen, Cho \& Meier, 2014) mengidentifikasi 4 tactics untuk menciptakan integrasi atau segmen yang jelas antara pekerjaan dan rumah yaitu behavioral, temporal, physical, and communication. Behavioral tactics berhubungan dengan melibatkan orang lain, temporal berhubungan dengan pengelolaan waktu, pembagian segmen pekerjaan dan rumah, strategi fisik yang berupa pengatasan jarak antar ranah peran dan strategi komunikasi. Dalam hal ini, kedua subjek melibatkan temporal tactics. "[...].Senin sampai jumat silahkan full dengan pekerjaan kantor.[...]. sabtu minggu memang full untuk keluarga" (381-396 P1).

"[...]. Senin sampe jumat itu memang benar benar buat kerja, buat sekolah. Sabtu minggu tu baru buat rumah. Buat rumah, buat anak-anak" (1242-1247 P2).

Dari segi tema pencapaian peran, kedua partisipan mengatakan bahwa selama mereka menjalani peran ganda, mereka sudah seimbang. Bagi partisipan 1, ia sudah seimbang karena ia sudah berbuat yang terbaik untuk keluarga dan juga untuk kantor. Teman kantor dari partisipan 1, menyatakan bahwa partisipan 1 total dalam menjalankan peran gandanya yaitu dapat mengurus suami dan kedua anaknya yang masih balita dan juga dapat tetap profesional sebagai jaksa. Sedangkan bagi partisipan 2, ia sudah seimbang karena segalanya telah berjalan dengan baik. Menurut keterangan suami partisipan 2, sejauh ini semua berjalan dengan lancar yaitu istrinya mampu mengerjakan semua tugas baik itu sebagai ibu dalam keluarga, istrinya mengerti kodradnya sebagai seorang wanita dan juga tetap profesional sebagai seorang jaksa. Anak-anak mereka tumbuh dengan perhatian dan kasih sayang yang cukup dari istrinya, tugas di kantor juga bisa diselesaikan tepat waktu. Menurut Fisher (2001), keseimbangan dapat terpenuhi ketika individu mempersepsi bahwa ia mampu memenuhi kebutuhan pekerjaannya tanpa harus mengganggu pemenuhan kebutuhan di luar pekerjaannya, dan sebaliknya (dalam Novelia, 2013).

"Hahaha kalo saya seimbang...saya rasa mungkin sudah ya..[...]. Kalo menurut saya sih, saya sudah berusaha semampu saya. Berbuat yang terbaik untuk keluarga, tapi berbuat yang terbaik juga untuk kantor" (1706-1723 P1).

"Eum... menurut saya, saya seimbang. Semuanya berjalan dengan baik. Gak ada masalah" (2081-2084 P2). 


\section{PENUTUP}

Kedua partisipan memiliki dinamika pengalaman work-life balance yang di dalamnya terdapat conflict dan enhancement yang tidak jauh berbeda. Kedua partisipan juga mempersepsi bahwa sejauh ini mereka sudah seimbang. Mereka telah berusaha untuk tetap profesional dalam pekerjaan dan juga tetap memiliki waktu dan perhatian bagi keluarga ataupun hidup mereka di luar kantor. Kedua partisipan menyatakan bahwa sejauh ini, mereka sudah merasa seimbang dalam menjalankan peran ganda mereka. Menurut Fisher (2001), keseimbangan dapat terpenuhi ketika individu mempersepsi bahwa ia mampu memenuhi kebutuhan pekerjaannya tanpa harus mengganggu pemenuhan kebutuhan di luar pekerjaannya, dan sebaliknya (dalam Novelia, 2013). Penelitian selanjutnya diharapkan dapat melibatkan partisipan dengan kriteria yang berbeda, misalnya dari segi pekerjaan dan jenis kelamin sehingga dapat memberikan gambaran work-life balance yang lebih khas.

\section{DAFTAR PUSTAKA}

Badan Pusat Statistik. 2016. Persentase tenaga kerja formal menurut jenis kelamin 2015-2016.Sumber https://www.bps.go.id/dynamictabl e/2018/05/16\%2000:00:00/1313/pe rsentase-tenaga-kerja-formal- menurut-jenis-kelamin-2015--2016.html

Badan Pusat Statistik. 2017. Profil Ketenagakerjaan Dan Pengangguran Provinsi NTT.Sumber dari https://ntt.bps.go.id/

Handayani, A., Afiati, T., \& Adiyanti, M. G. 2015. Studi eksplorasi makna keseimbangan kerja keluarga pada ibu bekerja. Seminar Psikologi \& Kemanusiaan. Malang: Universitas Muhammadiyah.

Hurlock, E. B. 1999. Psikologi Perkembangan. Jakarta: Penerbit Erlangga.

Putri, S. A. P. 2012. Karir dan pekerjaan di masa dewasa awal dan masa dewasa madya. Majalah Ilmiah Informatika, 3 (3), 193-212.

Novelia, P. 2013. Hubungan Antara Work-Life Balance dan Komitmen Berorganisasi pada Pegawai Perempuan. Fpsi UI, 09,1-19.

Fisher, G. G., Bulger, C. A., \& Smith, C. S. 2009. Beyond work and family : A measure of work/nonwork interference and enhancement. Journal of Occupational Health Psychology American Psychological Association, 14(4), 441-456.

Milkie, M., \& Peltola, P. 1999. Playing all the roles : Gender And The WorkFamily Balancing Act. Journal of Marriage and Family, 61(2), 476490.

Soetjiningsih, C. H. 2012. Psikologi Perkembangan. Jakarta: Kencana Prenada Media Group.

Poulose, S., \& Sudarsan. 2014. Work life balance : a conceptual review. International Journal of Advances 
in Management and Economics, 3 (2), 1-17.

Santrock, J. W. 2012. Perkembangan Masa Hidup (edisi 15). Jakarta: Penerbit Erlangga.

Presiden Republik Indonesia. 2004. Undang-Undang No. 16 Tahun 2004 Tentang Kejaksaan Republik Indonesia. Lembaran RI Tahun 2004. No. 16. Jakarta : Sekretariat Negara.

Goode, W. J. 1960. A Theory Of Role Strain. American Sociological Review, 25(4), 483-496.

Sieber, S. D. 1974. Toward A Theory Of Role Accumulation. American Sociological Review, 39(4), 567578.

Saniy 2018. Tipe Work-Life Balance Pada Pekerja Wanita Yang Sudah Menikah Di DP2KBP3A Kabupaten Bandung. Skripsi. Bandung : Universitas Kristen Maranatha.

Smith, J. A.,\& Osborn, M. 2009. Interpretative phenomenological analysis. London: Sage.

Bloom, B. D., \& Crabtree, B. F. 2006. The qualitative research interview. New Jersey : Blackwell Publishing.

Milkie, M. A., Kendig, S. M., Nomaguchi, K. M., \& Denny, K. E. 2010. Time With Children, Children's WellBeing, And Work-Family Balance Among Employed Parents. Journal of Marriage and Family, 72(5), 1329-1343.

Indriyani, A. 2009. Pengaruh Konflik Peran Ganda Dan Stres Kerja Terhadap Kinerja Perawat Wanita Rumah Sakit. Skripsi. Semarang : Universitas Diponegoro.
Wijayanto, A. Y., \& Fauziah, N. 2018. Kerja Di Genggamanku Keluarga Di Hatiku: Interpretative Phenomenological Analysis Tentang Work-Family Balance Pada Ibu Bekerja. Jurnal Empati, 7 (1), 76-83.

Allen, T. D., Cho, E., \& Meier, L. M. 2014. Work-family Boundary Dinamics. Anual Review of Psychology and Organizational Behavior, 1, 99-121.

Herdiansyah, Haris. 2015. Metodologi Penelitian Kualitatif Untuk Ilmu Psikologi. Jakarta: Salemba Humanika. 